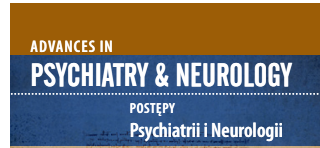

\title{
PROFESOR MARIA SIWIAK-KOBAYASHI - WSPOMNIENIE WSPÓŁPRACOWNIKA
}

Wejdź w samego siebie, we wnętrzu człowieka mieszka prawda. św. Augustyn

30 lipca 2020 r. zmarła Nasza Pani Profesor, Maria Małgorzata Siwiak-Kobayashi. Piszę te pożegnalne słowa jako przedstawiciel dawnych i obecnych pracowników Kliniki Nerwic, Zaburzeń Osobowości i Odżywiania Instytutu Psychiatrii i Neurologii w Warszawie. Nazywaliśmy ją właśnie tak - Nasza Pani Profesor. Mówiliśmy też Nasza Szefowa. Była osobą niezwykle pracowitą, odpowiedzialną i przyjaźnie nastawioną do ludzi. Pozostawiła po sobie ducha życzliwości. Sama nazywała siebie uczennicą profesora Stefana Ledera i kontynuowała jego dzieło, ubogacając je swoim wkładem. Była lekarzem, specjalistą psychiatrą, psychologiem, psychoterapeutą, superwizorem psychoterapii, naukowcem i nauczycielem wielu pokoleń psychoterapeutów.

Nie chciałbym tu przedstawiać całego bogatego jej życiorysu, wielkiego dorobku naukowego czy dydaktycznego. Jednak nie sposób nie wspomnieć o kilku rzeczach.

Studia medyczne ukończyła w 1966 r. w Lublinie. W 1969 r. uzyskała również stopień magistra psychologii na Katolickim Uniwersytecie Lubelskim. W 1969 r. podjęła pracę w Klinice Nerwic Instytutu Psychiatrii i Neurologii w Warszawie, stworzonej i kierowanej przez profesora Stefana Ledera. W 1975 r. obroniła rozpra-

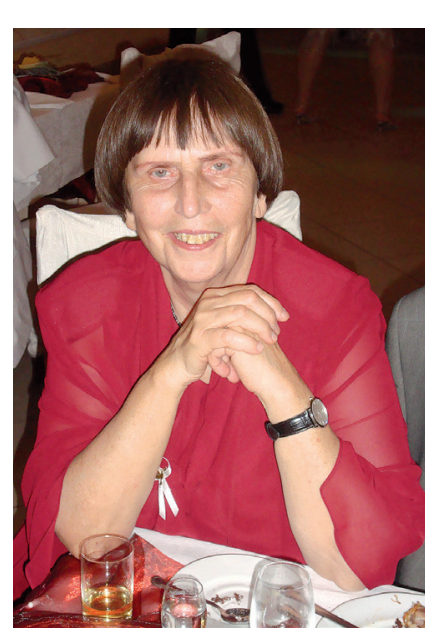

(1943-2020)
Psychoterapii Polskiego Towarzystwa Psychiatrycznego, której przewodniczyła w latach 1993-1997. Była pionierką i propagatorką terapii poznawczo-behawioralnej w Polsce, autorką rozdziałów poświęconych nerwicom w podręcznikach psychiatrii. Opublikowała dziesiątki prac naukowych dotyczących empirycznych badań mówiących o procesie psychoterapii i jej efektach. Brała aktywny udział $\mathrm{w}$ upowszechnianiu psychoterapii jako metody leczenia zaburzeń zdrowia psychicznego. Od początku wprowadzenia szkoleń dla psychoterapeutów uczestniczyła w nich jako prowadząca.

Pani Profesor zawsze na pierwszym miejscu stawiała pracę kliniczną, sprawy pacjentów, zrozumienie pacjenta jako człowieka. Pacjent nigdy nie był dla niej "przypadkiem” czy łamigłówką do rozwiązania, ale zawsze osobą oczekującą pomocy. I od nas wymagała, byśmy uczyli się najlepszych możliwych sposobów pomagania i potrafili dotrzeć do danej osoby. Uczyliśmy się od niej istoty kontaktu z pacjentem, znaczenia mówienia jego językiem, nieoceniania go, szacunku dla jego przekonań. Jej credo stanowiły właśnie słowa św. Augustyna: „Wejdź w samego siebie, we wnętrzu człowieka mieszka prawda". Ogromny szacunek dla ludzi, ich poglądów, przekonań był niezwykłą cechą Pani Profesor, świadczącą o jej wielkości. Odzwierciedlał to zarówno jej stosunek do pacjentów, jak i fakt, że w gronie jej współpracowników znajdowali się ludzie o podobnej wrażliwości, ale czasem także o odmiennych od jej własnych przekonaniach. Zajmowała się również dydaktyką. Zresztą za swoją pracę superwizora nigdy nie pobierała honorarium, uważając nauczanie kolegów za swój obowiązek.

Zainteresowania Pani Profesor były bardzo szerokie. Chciałbym podkreślić jej miłość do muzyki i znawstwo w tej dziedzinie, znajomość literatury i sztuki. Wszystko to potrafiła wykorzystać $\mathrm{w}$ pracy z pacjentami i dzielić się tym, by pogłębić z nimi kontakt. Uczyła nas, że z pacjentem trzeba mówić nie tylko znanym mu językiem, ale też o znanych mu i ważnych dla niego różnych sprawach, zainteresowaniach, pasjach, że nie można ograniczać się tylko do rozmowy o jego problemach. Pozwala to bowiem nie tylko nawiązać kontakt, ale też pomaga 
pacjentowi dostrzec i docenić swoją wartość w różnych aspektach jego życia. Pani Profesor pracowała z pacjentami do ostatniej chwili.

Pani Profesor była wymagająca, ale równocześnie była dla nas osobą bardzo bliską, żywo zainteresowaną naszymi sprawami. Była naszym przyjacielem, starającym się nieść pomoc w różnych sprawach (często bardzo osobistych) i towarzyszącym w radościach. Drzwi jej gabinetu zawsze stały dla nas otworem. Nie wyobra- żała sobie, by przed świętami Bożego Narodzenia mogło nie być wigilijnego spotkania. Zawsze organizowała je dla nas - dawnych i obecnych pracowników Kliniki Nerwic. W trakcie tych wigilii wspólnie śpiewaliśmy kolędy, a ona grała na fortepianie. Uważam, że otrzymaliśmy od niej bezcenny dar - gościnę i godne miejsce w jej domu i sercu.

Artur Krężel 